Introduction: Contaminated and Dislocated Bodies in Catalan Visual and Performance Cultures

Bru-Dominguez, Eva; Buffery, Helena

\title{
Journal of Romance Studies
}

DOI:

$10.3828 /$ jrs.2019.12

Published: 16/07/2019

Peer reviewed version

Cyswllt i'r cyhoeddiad / Link to publication

Dyfyniad o'r fersiwn a gyhoeddwyd / Citation for published version (APA):

Bru-Dominguez, E., \& Buffery, H. (2019). Introduction: Contaminated and Dislocated Bodies in Catalan Visual and Performance Cultures. Journal of Romance Studies, 19(2), 173-184. https://doi.org/10.3828/jrs.2019.12

\footnotetext{
Hawliau Cyffredinol / General rights

Copyright and moral rights for the publications made accessible in the public portal are retained by the authors and/or other copyright owners and it is a condition of accessing publications that users recognise and abide by the legal requirements associated with these rights.

- Users may download and print one copy of any publication from the public portal for the purpose of private study or research.

- You may not further distribute the material or use it for any profit-making activity or commercial gain

- You may freely distribute the URL identifying the publication in the public portal ?
}

Take down policy

If you believe that this document breaches copyright please contact us providing details, and we will remove access to the work immediately and investigate your claim. 


\title{
Introduction
}

\section{Contaminated and dislocated bodies in Catalan visual and performance cultures}

\author{
Eva Bru-Domínguez \\ Bangor University \\ Helena Buffery \\ University College Cork
}

If Catalan culture has been in the news in recent times, it is largely because of the international impact of what has come to be called the 'independence process' and its repercussions vis-à-vis the perceived social, political, and economic stability of Spain and, more recently, Europe. In many ways, this has been an unexpected development, with the region long viewed as somewhat of a success story for what Montserrat Guibernau (1999) has termed a 'stateless nation' in the years since Spain's Transition to Democracy, precisely because of the disproportionate strength - in relative terms - of Catalonia's cultural and economic presence on the world stage, especially within Europe, and because of the unusual vitality of the Catalan language, when compared with other minor or lesser-spoken languages. Furthermore, the post-Transition narrative of a plural Spain has long been held up as an exemplary case study of a plurilingual and multicultural state within Europe and has underpinned approaches to contemporary Iberian studies. The Catalan bodies that have been emerging in growing numbers on the streets of Barcelona over the past decade to protest against the policies of centralization within Spain, of austerity within Europe, against social and environmental injustice, and above all in favour of first the right to decide and then increasing degrees of secession since 2010, have come as a great surprise to many internal and external commentators and spectators, precisely because they do not appear to fit the previous frame of a successful Transition in Spain or of Catalan cohesion and 'convivencia' (Hall 2001). They have been read 
either as a reflection of global processes - the economic crisis, or the increasing turn towards exclusionary nationalism - or as symptomatic of particular social, political, and economic processes within Spain - the political turn to the right and increasing recentralization, the effects of historical memory discourses, problems of governance produced by the regional statutes of autonomy, and, above all, Catalonia's perceived lack of solidarity, read within narratives of Catalan self-interest that go back at least as far as José Cadalso's eighteenthcentury Cartas marruecas.

The events of 1 October 2017, when the some 2.5 million people who turned out to vote in a disputed referendum on Catalan independence did so at the risk of violent suppression by the Spanish police forces that had been building up in the region during the previous ten days, left the international community perplexed and desperately seeking readings in terms of legal, economic, political, and social context. These almost invariably failed to address the question of how to interpret, let alone respond to, the presence of so many human bodies intermingling and offering passive resistance in public space. Were they an example of a brain-washed population, contaminated by what many Spanish intellectuals diagnosed as a form of 'wounded narcissism'? Was this a displaced version of Reclaim the Streets, performed by middle-class Catalans as a form of dislocated spectacle? If this was a movement about separation, national purity, and exclusion, why did their corporal practices and dispositions speak of community, sensual empathy, and inclusion?

Whilst this special issue does not set out to offer a reading of urban social protest, or contain articles that address overtly and specifically the meaning of these particular Catalan bodies on the streets of Barcelona and other Catalan public spaces, it does call for attention to the significance of bodily presences and histories, and, by focusing on the corporeal in Catalan cultural practices, to the ways in which bodies intermingle and corporeal practices contaminate each other. Tracing the presence and absence of Catalan bodies across different spaces, cultural practices, moments, and cultural forms, this special issue evokes a wider context for understanding and attending to the bodies on the streets of Catalonia in October 2017 and earlier, and alerts us to the problem of their dislocation, their unintelligibility, and unrecognizability in much of the discourse that followed these events. Most obviously, and literally, some of the practices unveiled and traced in this issue reveal a genealogy of practice: the history of contemporary dance as a process of resistance and transmission; the importance of memory activism in bodily presences and absences; the relationship between body and landscape, and with non-human and animal lives; the search for forms 
of recording, preserving, and performing bodily experiences that challenge and dislocate the normative. This genealogy of practice frames and makes more intelligible the particular bodily relationships and dispositions to resist and protest that materialized in October 2017.

But the overarching aim of this special issue, reflected in each of the articles, is to explore ways of reading the corporeal from a position that is both dislocated and contaminated. Our navigation of the bodily turn that is so central to contemporary critical theory, philosophy, and ethics, with its focus on the universality of the material, the materiality of a universe of things, attends necessarily to particular bodies and their modes of being in place. These bodies are often misrecognized, dislocated, or marginal because of their geopolitical location or their dwelling in non-dominant languages, yet at the same time they are contaminated by the imprints of the global: they are bodies that contaminate through their excess and simultaneously draw attention to imprints of dislocation.

This special issue responds to the focus on the corporeal in critical theory and does so with an awareness of the difficulties of explaining Catalan culture to academic audiences due to the fragmentary nature of its international representation. This is caused by the prioritization of certain specific locations or genres (the Barcelona brand; Catalan Modernista architecture), attention to the individual genius of certain idiosyncratic artists (Salvador Dalí; Joan Miró), the primacy of comparative readings of the sociopolitical conditions for nation building in international social scientific analysis, and the dominance of the study of narratives (whether literary or filmic) within Iberian and Hispanic cultural studies approaches. Our central aim is to provide a space for reflection and critical analysis of corporeality in Catalan visual, activist, and performative practices. Interdisciplinary in ethos, this collection of articles brings together specialists in the fields of visual culture, performance art, dance, and cinema whose work engages with a broad spectrum of Catalan cultural production in the twentieth and twenty-first centuries. The major thread running through this issue is the urge to examine - critically and theoretically - the invisibility, displacement, and impurities of certain bodies and artistic practices in Catalan visual culture and performance, attending to the historical and geopolitical reasons for this.

While the representation of the human body has been a recurrent motif in visual art across different cultures and civilizations over the centuries, the study of corporeality has traditionally been associated with the natural sciences. The publication in the 1990s of groundbreaking works such as Judith Butler's Gender 
Trouble (1990), Elizabeth Grosz's Volatile Bodies (1994), and Rosi Braidotti's Nomadic Subjects (1994) went some way towards correcting this imbalance, generating a growing interest in the rethinking of the body across the humanities and social sciences. These theorists located the material body in relation to its sociopolitical context and addressed questions about sexuality, gender, and race while highlighting the potential of bodies to challenge or subvert the social, cultural, and political discourses that shape them into ideal (and normative) form. The view that bodies are not stable and coherent entities but the effects of social, sexual, racial, and political discourse has its roots in postmodernist thinking and its relentless questioning, and unsettling, of traditional notions of subjectivity. Since the 1990s, this understanding of the corporeal has informed critical analyses of visual culture and performance art, where, in the words of the art historian and critic Amelia Jones, performative practices are regarded as instantiating 'the dislocation or decentering of the Cartesian subject of modernism' (1998: 1). In such artistic forms, the presence and/or representation of a body that is decentred is often read as symptomatic of a fraying in dominant models of understanding identity, society, and culture.

Attention to the construction of gender, sexuality, and identity in the field of Hispanic studies has grown considerably since the publication of Helen Graham and Jo Labanyi's Spanish Cultural Studies in 1995 (see, for example, Jordan \& Morgan-Tamosunas 1998, 2000; Pavlović 2003) with a significant number of publications dedicated to examining critically the male body and, more specifically, masculine stereotypes and the hegemonic masculinities associated with notions of Spanishness (Fouz-Hernández and Martínez-Expósito 2007; Perriam 2003). While interest in the exploration of these issues is on the increase, focus remains on film and popular culture largely to the exclusion of dance, photography, creative activism, performance art, and installation. These omissions are even more apparent in the field of Catalan studies, where scholars based in Catalonia, especially, have traditionally avoided genderinflected approaches to creative production, deeming these to be historically and culturally reductive. In the past ten years, there has been an observable turn to the study of the body, with a rise in the number of scholars attending to questions of gender and national identity, corporeality, and embodiment, particularly with regard to literature but also to cinema (Fernàndez 2008a, 2004, 2012). These studies have tended to draw on the Butlerian notion of performativity to explore narrative forms, opening them up to a theoretical framework that had previously been applied mostly to the analysis of performance. This research has been particularly important in contesting the prioritization of a 
male-dominated canon within twentieth-century Catalan cultural history, but has also led to diagnosis and analysis of anxieties about the monstrosity of the Catalan body due to its cultural invisibility and marginalization. In some of Ventura Pons's films, for example, the representation of physical illness and/ or the non-normative racial, gendered, and sexual other has been interpreted as a metaphor for an ailing and mutating social body (D'Lugo 1997; Fernàndez 2000, 2008a, 2008b, among others). Scholars investigating the configuration of the body and gender in literature and the cinematic texts include the Universitat Autònoma de Barcelona's research group 'Cos i textualitat' ['Body and Textuality'], whose research has been published in two influential outlets: the journal Lectora: Revista de dones i textualitat and the Mujeres y Culturas series for Icaria editorial, while in the field of dance, the recent collection on 'Danza y Pensamiento' ['Dance and Thought'] co-published by the Mercat de les Flors, Institut del Teatre, and Ediciones Polígrafa, has made a significant contribution to interdisciplinary thinking about the imbrications of body, performance, and politics. More specifically focused on Catalan visual and performance cultures, Helena Buffery and Carlota Caulfield's Barcelona: Visual Culture, Space and Power (2012), explores the relationship between space and cultural practices in a range of visual artists, festive popular practices, puppeteers, performers, and choreographers, broadening the field of study to art forms that have often been overlooked. Three articles in the volume's final section, 'Performing Barcelona', examine a variety of corporeal interventions on both the stage and in urban space (by Buffery, Delgado, and Astles).

Despite the diversity of analyses outlined above, critical investigation to date of the construction of corporeality in Catalan artistic production remains incipient and mostly centred on literary or filmic forms. Furthermore, investigations of the body, gender, and sexuality have also been neglected until recently by academics working in the disciplines of art history, criticism, and curatorship in Catalonia, who have traditionally favoured historiographical approaches (Parcerisas 1994, 2007). Scholars who buck the trend include, most prominently, art historian and critic Pere Salabert (2007), whose comprehensive volume El cuerpo es el sueño de la razón y la inspiración una serpiente enfurecida ['The body is the dream of reason and inspiration an enraged serpent'] draws on psychoanalytical theory to discuss the construction of the male body and masculine sexuality in the work of the multidisciplinary performance artist Marcellí Antúnez, as well as more recent curatorial work, such as Maite Garbayo Maeztu's Cuerpos que aparecen. Performance $y$ feminismos en el tardofranquismo (2016) ['Bodies that appear: Performance and feminisms in late Francoism']. Offering a feminist account of 
performance art during the last decade of the dictatorship and the early years of the transition to democracy, the latter acknowledges the legacy and influence on the Spanish artistic arena of many artists working in Catalonia in the 1970s and 1980s (Jordi Benito, Olga Pijoan, Àngels Ribé, Carlos Pazos, Fina Miralles, and Ocaña). Basing her analysis on the work of Michel Foucault and Judith Butler, Garbayo Maeztu examines the politicization of the body of the artist/performer, questions of corporeal presence, and the significance and effect of physical interventions (actions, happenings, and performances) in and on the built and natural environment.

In the past twenty years, debates on corporeality have focused primarily on the discursive construction of the body, relations of power, nomadic identities, race, gender, and sexuality. More recently, the publication of Grosz's Becoming Undone (2011) and Braidotti's The Posthuman (2013) has opened up new areas of investigation concerning the limits of the human and its connection to the animal, the vegetable, and the virtual worlds, as well as the decentring of the (male) body as a source of all knowledge. While discussion of the posthuman condition had thus far been associated with feminist theory and, in particular, with Donna Haraway's seminal essay 'Cyborg Manifesto' (1985), these authors traverse the realms of gender and sexuality studies and situate their exploration of the so-called posthuman condition in relation to ethics, the natural sciences, and philosophical thought. Braidotti's critique emerges from an anti-humanist stance, whereas Grosz draws on the writings of Darwin and Deleuze to locate the human on a continuum with animal and vegetable species. In the field of Spanish cultural studies, the conference 'Animals in Visual Hispanism' hosted by University College London on 9 September 2016, curated by Jo Evans and Sarah Wright, evinces the late turn in the discipline to critical investigation of posthumanism and animal studies, resulting in a special issue that launched the new Bulletin of Spanish Visual Studies.

Notwithstanding the gradual increase in analyses of corporeality, scholarly investigation of bodily matters in Catalan visual arts and performance remains largely in its infancy, and there has been little attention to the intermingling, contamination, and dissemination of practice across and between different media and cultural and disciplinary boundaries. Performance, ritual, dance, and photographic images of the body have been - and remain - core elements and activities in the production of visual, performance, and popular festive cultures in Catalonia. Undoubtedly, such corporeal utterances, iterations, and figurations have played a symbolic role in processes of identity formation, and visual art practitioners, film-makers, dancers, and performers continue to show a concern 
with questions of embodiment, body limits, hybridity, and displacement. The visibility and presence of the body in Catalan cultural production requires richer critical engagement that expands the narrow, mostly masculine, focus of the canon and accounts for a range of bodies that have, thus far, been excluded from scholarly research. In order to make this phenomenon intelligible within Catalan, Spanish, and European popular, visual, and performance art studies, analysis of the corporeal also demands a broader transversal theoretical approach that moves beyond the Butlerian performative.

The different contributions in this issue draw on insights from critical theory, art history, film studies, performance, and gender studies to consider a range of cultural products, including dance, installation art, performance, photography, and cinema. They present numerous examples of contaminated and dislocated bodies that challenge traditional notions of the centrality of (masculine) corporeality in respect to cultural, political, and spatial realms. The articles centre on body displacement and the incorporation and/or embodiment of foreign, non-normative, and, therefore, impure social, sexual, cultural, and political values. Corporeal and sexual identities are forged in collaboration with multiple variables, which need to be accounted for; they are complex and nomadic in nature and resist historical and cultural reductionism. The bodies studied here do not conform to an ideal normative but are contingent and, as such, susceptible to hybridizations and contaminations (cultural, temporal, racial, animal, and sexual).

As Carlota Caulfield explains in the first article in this issue, the early twentieth-century Barcelona-based dancer, Tórtola Valencia, with her fetishized (and fascinating) Otherness and multiple and unfixed gendered, cultural, and national on- and offstage identities, emerges as the embodiment of fin-de-siècle anxieties, that is to say, as a contaminated and dislocated body that transgresses traditional geopolitical, aesthetic, gendered, and cultural boundaries. In fact, not only was Valencia's corporeal identity situated at the borders of normativity, but her dance also incorporated extraneous elements from Spanish, Latin American, African, and Asian popular culture and folklore, as well as contemporary literary and artistic movements such as Noucentisme, Modernisme, and the European avant-gardes. Rather than dwelling further on the hitherto-studied topic of female objectification and masculine ocular-centrism, Caulfield's research into Valencia's archive, attending to archival remains of her performances, unveils the conflicting discourses that are actualized through the movements of the dancer and give shape to the contours of her body, revealing her as a body of dissensus that 'actively challenges binary distinctions between public and private, masculine 
and feminine, mind and body, archive and repertoire, simultaneously signalling and calling for new ways of knowing through the embodied experience of the contemporary dancer' (p. 186).

In his analysis of Marc Recha's representation of the male body on the screen, Anton Pujol suggests that, in line with formulations of the postmodern subject, the director posits a challenge to both the physical and optical centrality, and centredness, of man. He notes the relative invisibility of masculine corporeality in contemporary culture's visual economies and analyses the displaced status of the naked male body in two of Recha's films and one paratext. Pujol draws on a theoretical corpus of work that emerged in the 1980s and 1990s as part of gender studies' dismantling of binary notions of gender and sexuality, which began to examine critically the transcendent and hegemonic status of (heterosexual) masculinity in systems of power and to account for, as well as resituate, marginal forms of male corporeality and subjectivity. Informed by Fouz-Hernández and Martínez-Expósito's 2007 exploration of Spanish film's construction of a male body in crisis, the article examines counter-hegemonic constructions of corporeality in Pau i el seu germà (2001) and Dies d'agost (2006). Pujol argues that the dislocated status of the male nude in relation to stable notions of masculinity in these films is symptomatic of a weakening of discourses on sexual as well as cultural (national) identity. Moving beyond theoretical formulations of 'masculinity in crisis' to locate male corporeality in overt relationship with the environment, Pujol argues that in these two films, the male body and the landscape it inhabits are constructed as malleable surfaces that bear the scars of the subject as well as those of the collective. For Pujol, these wounded corporeal and geographical topographies emerge as fragmented, incoherent, and only partially visible terrains, a visual and conceptual strategy that is also echoed in the elliptical narrative of Recha's films. The mode of portrayal of masculinity in crisis in these films thus signals the same kind of blind spot evoked in Bru-Domínguez's article in this issue, drawing attention to 'remnants of past, embodied experiences, and emotions' (p. 277) that challenge the pressure to elide difference and dissensus characteristic of heteronormativity, neoliberal capitalism, and the nation state.

The question of the invisibility of the body arises again in Anna Titus's article, which examines the dislocation of marginal and oppressed (female) bodies in three photographic series by Mariona Giner: Relats curts de la Mina (2003) ['Short Stories of La Mina'], Públic/Privat (2004-2005) ['Public/Private'], and Wad/Ras'92 (1992). Noting the mechanisms of selection intrinsic to the photographic archive, understood as an institutional instrument of memory 
storage and transmission, Titus argues that Giner's photographic documentaries of female prostitution, different gypsy communities, and the female prison population unsettle the power structures that categorize and determine the legitimacy of certain types of bodies to occupy a place in the historical record, by drawing attention to and critiquing the role of the archive as an apparatus for selecting and classifying subjectivities. For Titus,

The bodies of the subjects [Mariona] Giner portrays in her work bear the traces of their social environment. By visually documenting these subaltern and invisibilized characters, her work engages with questions of gender's relationship to and mediation of social disadvantage and the discourses implicit in the rendering of female corporeality. (p. 230)

Noting the scant attention given to gender in the archive in Catalan scholarship, Titus locates her analysis of Giner's images at the crossroads of gender, sexuality, and power (as formulated by Butler) and draws on postcolonial critique of the subalternity of women (as theorized by Gayatri Chakravorty Spivak) to explore how the presence of these contaminated and polluting bodies problematize gender-inflected processes of legitimization and policing of the boundaries between public/private, interior/exterior, and self/other. Above all, however, she reveals a photographer whose practice invokes a form of memory activism, committed to the de-spectralization of disadvantaged social groups.

The relationship between the body, memory, and space is in turn examined by Eva Bru-Domínguez in her article on two works by the multidisciplinary artist Eulàlia Valldosera: the performance/installation The Navel of the World (1991) and the photographic series Family Ties (2012). The study draws on the notion of indexicality, described as the trace of bodily gesture and action left on the photograph (or canvas), and the history-laden concept of shadow as the residue of bodily matter and a means to represent three-dimensional space as well as psychological depth. Valldosera's work is situated in relation to the conceptual turn in the international arts arena, described by art critic Arthur Danto as 'the end of art', that originates in the 1960s and brings about a shift towards ephemeral and performative means of artistic creation. Bru-Domínguez argues that, in line with these new developments in the arts, Valldosera's work explores questions of (female) embodiment, cultural heritage, and memory trace and, in so doing, engages critically with her most immediate socio-historical context. In Bru-Domínguez's reading, the artist attempts to cleanse and release the body from the stagnant and contaminated environment it inhabits; in other 
words, Valldosera's art proposes to dislodge the material subject from the iterative social mores and practices that mould it into normative and legible sociability. Furthermore, the very indexicality of Valldosera's works is imbued with an 'affective charge [... that] pricks the viewer and forces them to reconstruct the histories in the same way as the brain reconstructs that which the retina cannot reproduce visually' (p. 278). In this way, Valldosera's images call for attention and empathic identification on the part of the viewer to respond relationally to the singularity of different corporeal experiences.

Finally, Elisenda Marcer's article also questions the notion of the normative and socialized body in her analysis of the limits between the realms of the human and the animal in Agustí Vila's film La mosquitera (2010). She locates the film in relation to a tradition in European cinema that engages with the animal as a means to address philosophical, ethnographic, and ethical questions. Drawing on contemporary scholarship in the field of animal studies and placing it in dialogue with André Bazin's reconceptualization of the material ontology of film, Marcer analyses questions of materiality and vulnerability in order to consider the aesthetic and ethical relations and responses elicited from the spectator. Her exploration of animality in the film entails 'an investigation of how animals figure as part of the plot; the forms in which they feature [...]; and the manner in which their rules and behaviours become more prevalent [...] gradually transforming the human habitat into an animal one' (p. 284). The contaminated and dislocated bodies and behaviours produced by the intermingling of different species in the film draw attention to the socially constructed limits of the human, whilst the cinematographic focus on physical and material contingency beckons us to move beyond the dominant anthropocentric worldview and to apprehend, with Michel Serres, that:

Contingency means mutual touching: world and body meet and caress in the skin. I do not like to speak of the place where my body exists as a milieu, preferring rather to say that things mingle among themselves and that I am no exception to this, that I mingle with the world, which mingles in me. (Serres quoted in Connor 1999: 157)

These are the limits that Vila seeks to extend in his film, invoking the same kind of engaged and empathic attention to the material and corporeal traces we have sought to imagine, perform, and contain, if only provisionally and ephemerally, in this issue as a whole. 


\section{Works cited}

Braidotti, Rosi (1994) Nomadic Subjects Embodiment and Sexual Difference in Contemporary Feminist Theory (New York: Columbia University Press).

Braidotti, Rosi (2013) The Posthuman (Cambridge: Polity Press).

Buffery, Helena, and Carlota Caulfield (eds) (2012) Barcelona: Visual Culture, Space and Power (Cardiff: University of Wales Press).

Butler, Judith (1990) Gender Trouble: Feminism and the Subversion of Identity (New York and London: Routledge).

Connor, Steven (1999) 'Michel Serres' Le cinq sens', in Mapping Michel Serres, ed. Niran Abbas (Chicago: University of Michigan Press), 153-169.

D'Lugo, Marvin (1997) 'La teta i la lluna: The Form of Transnational Cinema in Spain', in Refiguring Spain: Cinema/Media/Representation, ed. Marsha Kinder (Durham: Duke University Press), 196-214.

Fernàndez, Josep-Anton (2000) Another Country: Sexuality and National Identity in Catalan Gay Fiction (Leeds: Maney for the Modern Humanities Research Association).

Fernàndez, Josep-Anton (2004) 'The Authentic Queen and the Invisible Man: Catalan Camp and its Conditions of Possibility in Ventura Pons's Ocaña, retrat intermitent', Journal of Spanish Cultural Studies 5.1: 83-99.

Fernàndez, Josep-Anton (2008a) 'Immortal/Undead: The Body and the Transmission of Tradition in Amic/Amat (Ventura Pons, 1998)', in Burning Darkness: A Half Century of Spanish Cinema, ed. Joan Ramon Resina (New York: State University of New York Press), 211-233.

Fernàndez, Josep-Anton (2008b) El malestar en la cultura catalana. La cultura de la normalització 1976-1999 (Barcelona: Editorial Empúries).

Fernàndez, Josep-Anton (2012) 'Translating the Enigma: Temporality and Subjectivity in Ventura Pons's Barcelona (un mapa)', in Barcelona: Visual Culture, Space and Power, ed. Helena Buffery and Carlota Caulfield (Cardiff: University of Wales Press), 119-132.

Fouz-Hernández, Santiago, and Alfredo Martínez-Expósito (2007) Live Flesh: The Male Body in Contemporary Spanish Cinema (New York: Tauris).

Graham, Helen, and Jo Labanyi (1995) Spanish Cultural Studies: An Introduction (Oxford: Oxford University Press).

Grosz, Elizabeth (1994) Volatile Bodies towards a Corporeal Feminism (Bloomington: Indiana University Press).

Grosz, Elizabeth (2011) Becoming Undone: Darwinian Reflections on Life, Politics and Art (London: Duke University Press).

Guibernau, Montserrat (1999) Nations without States: Political Communities in a Global Age (Cambridge: Polity).

Hall, Jacqueline (2001) Convivencia in Catalonia: Languages Living Together (Barcelona: Institut d'Estudis Catalans). 
Jones, Amelia (1998) Body Art: Performing the Subject (Minneapolis: University of Minnesota Press).

Jordan, Barry, and Rikki Morgan-Tamosunas (1998) Contemporary Spanish Cinema and Genre (Manchester: Manchester University Press).

Jordan, Barry, and Rikki Morgan-Tamosunas (2000) Contemporary Spanish Cultural Studies (London: Routledge).

Parcerisas, Pilar (1994) Ideas \& Attitudes: Catalan Conceptual Art 1969-1981 (Manchester and Southampton: Cornerhouse and Hansard Gallery).

Parcerisas, Pilar (2007) Conceptualismo(s) poéticos, politicos y periféricos. En torno al arte conceptual en España, 1964-1980 (Madrid: Ediciones Akal).

Pavlović, Tatjana (2003) Despotic and Transgressive Bodies: Spanish Culture from Francisco Franco to Jesús Franco (New York: State University of New York Press).

Perriam, Christopher (2003) Stars and Masculinities in Spanish Cinema: From Banderas to Bardem (Oxford: Oxford University Press).

Salabert, Pere (2007) El cuerpo es el sueño de la razón y la inspiración una serpiente enfurecida (Murcia: Cendeac). 